\title{
The inmigrants' associatons at Spanish School: A intercultural education proposal
}

\author{
Soriano-Ayala, Encarnación ${ }^{1}$, González-Jiménez, Antonio José ${ }^{1 \mathrm{a}}$ \\ ${ }^{1}$ Universidad de Almería, Spain. Ctra. De Sacramento, s/n. 04007
}

\begin{abstract}
This qualitative research is based in the ethnographic method. With this research we are trying to know the collaborative capacity and contributions that immigrants 'associations could do to the schools that form part of a social context characterised by the recent and massive arrival of immigrants. The information coming out from immigrants shows up that the participation of associations, besides to do a good intercultural work and favour the identity signs of new students, empower the school influence of immigrant children. In addition to, this participation would support the continuity between the school and the student family; it also constitutes a way of working with children and young people in communities of learning.
\end{abstract}

Keywords : Immigrants' associations; intercultural education; intercultural mediation; auimmigrant students and immigrant students' families.

\section{Introduction}

Auto In post-modern society, the rapid waves of migration/immigration are not a new phenomenon, what is new is their quantities and adaptation strategies. At present, approximately 170 million people live away from their countries of origin. It is as if everyone is all over the world, which means that people with different cultural and social referents are sharing time and space, [9].

Spain, which has been a migration country historically, has started to undergo a demographic transformation with the arrival of people from different cultural origins that will have a deep impact on the future of this democratic country.

The decade of the seventies marks an important point in the history of Spanish migration: the number of Spaniards migrating to foreign countries decreases significantly, whilst the number of foreigners immigrating to Spain increases considerably. In 1975 there were 165,000 alien residents, whereas in 1992 the number of foreign adults registered

\footnotetext{
${ }^{a}$ Corresponding author: author@e-mail.org
} 
reaches the figure of 415,000 and at the end of December of 2005 the number of registered aliens is 3.730 .610 , [10].

We live in societies that are becoming increasingly pluralistic. According to Habermas, there is "constant evidence of how they drift further and further apart from the model of a National State with a culturally homogeneous population. Multiple lifestyles, ways of life, ethnic groups, religious faiths are on the increase (...)". Citizens should be able to experience the use of their rights in terms of social security and the mutual recognition of the different ways of life and variety cultures. This is a society in which new ways of selforganisation are becoming apparent in its citizens, [4]. New citizen entities are coming into being such as NGOs, Foundations, social initiative Cooperatives... and those Associations aimed at protecting the rights of their members and to preserve acceptable living conditions to build a fairer, more committed and supportive society. These new entities arise as a consequence of the incapacity of the Government to ensure quality services for its citizens whether they may be autochthonous or immigrants and to report before public opinion certain problems not covered by the State.

As a fundamental element of the new self-organizations we have immigrants' associations, which form a space where solidarity is encouraged and the construction of the cultural identity of the immigrant is supported between the country of origin and the adoptive country, [6]. In these associations, immigrants exchange their experiences in the new life cycle they have started, which implies a re-encounter with their countries of origin. Inside these associations, there is mediation and dialogue between immigrants, [13, 12 and 7].

Immigrants' associations generally include a series of fundamental characteristics: 1) They are a meeting place where immigrants can disseminate their culture, customs and values. This activity encourages learning about one another, which is necessary to overcome social prejudices, [1], 2) The affirmation of identities and communities aids the development of collective identities, peaceful coexistence, satisfies the need for togetherness, [5], 3) Presupposes an exercise in active citizenship to improve the quality of life of immigrants and their host country. Immigrants' associations also have an educational function , [3] for they play a socializing role; they transmit solidarity, philanthropy and tolerance values, they constitute a space to promote awareness and make an impact on public and political opinion about the social problems that immigrants encounter and increase the sensitivity of citizens to the problems of immigrants, [8].

\section{Methodology}

With this qualitative investigation we seek to make known the educational capacity and contributions that immigrants' associations can make to the schools of Southern Spain, that is to say, a social context characterized by the recent and massive arrival of people from the Maghreb, from countries south of the Sahara Desert, from South America and from Eastern Europe. Our research is developed in two phases. This ethnographic research is developed in two phases.

\subsection{Phase I}

Once the immigrants' associations located in the South of Spain were chosen, we proceeded to invite them all to participate in our study. Only 16 accepted whose characteristics in terms of nationality are as follows: Three immigrants' associations from Morocco, of which one consists of women working on gender issues, one immigrants' association from Mali, two come from Senegal, one from Guinea Bissau, one from Guinea Conakry, one from Ghana, two from Russia, one from Mauritania, one from Pakistan, one 
composed of immigrants from different nationalities, one federation of immigrants' associations, one formed by immigrants from several African countries. The data collection techniques used in this phase have come from observing participants (field diary), in-depth interviews, and the discussion group.

In-depth interviews: Before carrying out the interviews, we visited and had contact with each one of the associations that agreed to participate in this research work. Subsequently, a guide script with open questions was prepared, from observing the activities carried out by the associations and the conversations held with their representatives. The drafted interviews were categorized and codified to be computerized at a later stage using the programme AQUAD version 5.7.

The discussion group: Once the information derived from the in-depth interviews was analyzed, a discussion group was formed. The use of this technique as a means for data collection is based on validating the different opinions and conclusions drawn from the interviews. The discussion group was formed by representatives from 7 immigrants' associations: Moroccan women association, Senegalese immigrants' association, Guinea Bissau immigrants' association, Ghana immigrants' association, Russian immigrants' association, Moroccan immigrant workers association and Moroccan immigrants' association. To categorize and codify the information obtained from the discussion group, the category system used in the in-depth interviews was utilized, since one of our aims was to contrast the information from the in-depth interviews with that obtained in the discussion group.

Participant Observation (Field diary): Participant observation took place through our participation in the activities of the immigrants' associations. To obtain all the necessary information we used a field diary, in which we wrote down all the descriptions of the events that occurred without contaminating or manipulating them.

This field diary is relevant because it plays an important role to answer certain questions that cannot be accessed through the in-depth interview and to contrast information.

\subsection{Phase II}

Finally, in third phase, all the information acquired in the previous phases is methologically contrasted (In-depth interviews, discussion group and field diary).

\section{Results}

The results presented come from the methodological triangulation of the information from the in-depth interviews, the discussion group and the field diary with the immigrants' associations.

For a better understanding, we organized the results by aspects that we considered fundamental for our research objectives.

\subsection{Reasons that justify the participation of immigrants' associations in the schools according to these associations}

The main reasons expressed by the representatives of the immigrants' associations to justify their presence in education centres are collected in four broad dimensions: teaching collective, immigrant and autochthonous families and immigrant and autochthonous students. 
The Teaching collective: The immigrants' associations point out the resistance of some teaches to deal with the subject of interculturalism in their classrooms and they feel there is little motivation amongst teachers to integrate immigrant students. They complain about the absence of classroom activities aimed at encouraging equality, valuing others that are considered different and respect to cultural difference. The also refer to the lack of support activities organised by the educational community outside school hours. In the words of one of the interviewees from a Senegalese immigrants' association: "Basically, it is the parents and then the teachers who fail to make the effort to get autochthonous and immigrant pupils to work pedagogically on the same level, i.e., in activities that encourage equality, I don't know how to explain it, but you understand what I want to say."

Immigrant students' families: Throughout the investigation we appreciated how the interviewees explicitly acknowledged that the integration problem lies not only with the teachers or the Administration, but that the families of immigrant students are also responsible, due to their scarce participation in schools. One representative of a Pakistani immigrants' association expresses this as follows:"(Children) do not integrate educationally. The parents are also to blame because they do not take an interest in their children's education. I believe that from the associations we must make parents aware of the importance of their collaboration in their children's education."

Autochthonous students' families: Immigrants' associations highlight the crucial role that the families of local students play transmitting discriminating behaviours and stereotypes of immigrants. It is therefore necessary to design actions that will bring the locals and the immigrants closer. In the words of a member of a Russian association:"I think it is not just racism because they are too young to understand and practise this concept, I think the problem is in the families, because they instil a negative behaviour towards these children".

Autochthonous and immigrant students: The existing problems between immigrant and local students are above all one of coexistence due to the culture shock that occurs between them and between the different male and female immigrant collectives. A Moroccan woman says this:"A rapprochement between us and the locals is very important. It is necessary to do whatever it takes for this to happen. It is the best way of getting to know one another and of doing away with stereotypes. For example, the other day a boy came and said to me that he did not expect to see a Moroccan woman using a computer".

\subsection{Proposals for the participation of immigrants' associations in education centres according to the own associations}

In terms of the coexistence problems that have arisen between cultures, the immigrants' associations proposed their participation as intercultural mediators with the following agents of the education community: local and immigrant students, teachers and local and immigrant families.

Mediation with local students: The associations defend the idea that developing intercultural mediation aimed at local and immigrant pupils from an early age will allow good relationships to develop amongst them, that is to say, positive coexistence between cultures and the eradication of the negative attitudes and stereotypes that local children have with regard to immigrants.

To this end, they propose to collaborate with education centres to carry out the following activities:

- Intercultural programmes or activities that will prepare local children from an early age to accept immigrants. In the words of one of the immigrants from Guinea Bissau and a member of this association: 
"It is also necessary to prepare local children to accept immigrants, whether it is through intercultural activities or programmes. Firstly they should be taught to adapt to the knowledge of and coexistence amongst cultures and then integration will take place. These are two different stages that must be worked upon with local and immigrant children from an early age. It does not mean that all students will accept immigrants, some will fail to do so, but others will succeed. It is important to work against the stereotypes they have of us, therefore, the associations can collaborate to change these negative attitudes to immigrants".

Mediation with immigrant students: The various immigrants' associations point out the need of an intercultural mediator of the same nationality as the immigrant pupils in schools or their own participation as mediators. These proposals are justified by two reasons:

1. The presence of mediators from the same cultural group in schools has a positive impact on the self-esteem of immigrant children, on their expectations for the future and in the valuation that local children make of the minority group. This type of participation can be observed in the following example expressed by an immigrant from a Moroccan association:

"The presence in schools of adult immigrants is necessary for immigrant children, whether they are mediators or work in another capacity, because this raises their selfesteem, their expectations for the future. This adult is a referent for them and they see themselves valued, that is to say, the child feels valued and not inferior to the others. What schools need is monitors or mediators of the same nationality as the immigrant pupils. For example, when Moroccan children are fighting or arguing, they listen to me, they feel more secure, more confident and stronger, they feel they are not a minority in the school and this increases their self-esteem."

2. The mediators of equal nationality than the immigrants are the educational agents who better know the culture of the immigrant student body and can intervene in the different cultural conflicts.

Mediation with teachers: The associations agree that one of the greatest problems teachers encounter is the lack of time for intercultural activities, to learn about the different cultures of their students and their belief that the presence of immigrant pupils has a negative impact on the academic process of local students. Two representatives of immigrants' associations from Guinea Conakry and Mauritania express their respective opinions in this way:

"Teachers must be made aware of the importance of their participation. Some teachers tell us that the presence of immigrants in schools lowers the performance levels of the other students and that they need help to develop their lessons correctly. I think we can be of assistance as mediators in this respect".

"I have worked as a mediator for two years in Roquetas de Mar. The problem is that Spanish teachers are not sufficiently prepared to attend to this collective and the main obstacle is that they are familiar with only one culture, the Spanish one. Teachers do not integrate immigrants either educationally or socially, for example, they state that spending time with an immigrant student causes academic delay to the local students. Neither do they take action to make immigrant and local children play together during the break."

Faced with this view, the associations propose the following collaboration actions:

-To supply teachers with materials and resources that will encourage the development of interculturalism, as a representative of a Russian association justifies: "I believe that associations should support the schools and collaborate with them in any activity that will aid the integration of immigrant children and their friendly coexistence with the local pupils. How can this be achieved? By means of awareness activities, through a closer acquaintance, giving the teachers, as my colleague from Senegal proposed, books and items from our country. We also need to train the teachers on our customs, cultures." 
-To collaborate with the teachers in the design and development of various intercultural activities proposed by the education community.

-To train in and inform teachers of the main aspects of the different cultures of their students.

Mediation with the families of autochthonous students: One of the great obstacles facing immigrant students is the upbringing local children receive from their families. According to the interviewees, families transmit negative attitudes and stereotypes with regard to immigrants, i.e., they point out that parents make derogatory comments about the way immigrants dress or about their customs. Two immigrants from a Moroccan and a Senegalese association respectively express this in their own words: "When children are young, i.e. in infant education, there are no problems, but as they grow up, problems start. When they reach the age of ten, immigrant and local children, start to form little groups and see other groups or gangs as rivals. This is due to the negative education that local children receive with regard to immigrants. It sounds strange to hear children in infant education say that in their class there are moors and blacks when they still don't know the colours."

"I think that the problem that immigrant children have is a handed on from parents to children, that is, if parents see the immigration phenomenon as a problem, their children will see it in the same way. Spanish parents have a negative preconception of immigration."

The solution proposed by the associations is intervention with families through intercultural mediation to provoke a change in the attitude of the parents and in the way they bring their children up in this respect.

Mediation with the families of immigrant pupils: All the associations interviewed proposed intercultural mediation with families to attain the following objectives:

-To inform families of the importance of daily attendance to school, that is, to fight against school absenteeism.

-To involve families in the education of their children.

-To increase the participation of families in the various activities carried out in education centres.

-To establish links between immigrant and autochthonous parents and the school.

As an example, a representative of a Moroccan immigrants' association illustrates these ideas in the following paragraph: "We must also inform the parents of immigrant children of the relevance of their children's daily attendance to school, of the legal consequences of their failure to attend; we also need to increase parents' participation, link families to the school and the teachers".

\section{Conclusions}

With the arrival of immigrants, the Spanish society is no longer a monocultural state. Schools reflect the model that society is experiencing and are no longer responding to the same cultural design. The number of students with different experiences of life, religion, language and customs has increased. The phenomenon is relatively recent and schools need new ways of understanding education. As a response to this new way of understanding schools we have investigated how they could use the knowledge of immigrants' associations, the main conclusions we have drawn from our study are as follows:

1. There is willingness and an interest in teachers and immigrants' associations in Southern Spain to collaborate and complement each other in actions and activities to improve the integration of immigrant children and young people.

2. Immigrants' associations coincide on the problems presented by immigrant and local students, teachers and immigrant families. They also agree on the necessity of Immigrants' 
associations to participate in education centers to overcome these obstacles through developing intercultural mediation, a closer relationship between immigrant families and schools and with activities that encourage cultural familiarization.

3. Teaching and learning are social acts that require a process with continuity amongst education agents, one of them being immigrants' associations.

4. The participation of immigrants' associations in schools and with other education community agents will aid the creation of learning communities where friendly coexistence and understanding between cultures will be the main objectives.

\section{References}

1. Fernández, J.S y Otros : "El asociacionismo inmigrante en Andalucía: diferentes perspectivas". En II Seminario de Investigación de la Inmigración Extranjera en Andalucía (pp. 210-222). Sevilla, Dirección General de Coordinación de Políticas Migratorias y Consejería de Gobernación de la Junta de Andalucía, (2002).

2. González-Jiménez, A.J, El desarrollo de la ciudadanía activa, crítica e intercultural mediante la participación de alumnado en las asociaciones, $\mathrm{ONG}^{\prime} \mathrm{S}$ y fundaciones. En E. Soriano (Coord.), La interculturalidad como factor de calidad educativa (pp. 215245). Madrid: La Muralla, (2005).

3. González-Jimenez, A.J., Las asociaciones de inmigrantes como espacio de formación educativa, mantenimiento y difusión de su identidad cultural y su participación en los centros educativos. Tesis Doctoral Inédita. Área de Métodos de Investigación y Diagnóstico en Educación. Universidad de Almería: España, (2006).

4. Mezzana, M., "Inmigración y multiculturalidad. Una reflexión andinoamericana". En M. García, M. Martínez y F, Santoloya (Coords). Integración social y empleo: El programa de Integra Diversidad (pp.105-118). Sevilla, Junta de Andalucía, (2003).

5. Pérez, L y López, J., El Tercer Sector en España. Madrid, Ministerio de Trabajo y Asuntos Sociales, (2003).

6. Sipi, R., "Las asociaciones de mujeres, ¿agentes de integración social?", Papers, 60, 355-364, (2000).

7. Sleeter, C. E., Diversity, social justice, and resistance to empowerment . In J. DeVitis \& K. Teitelbaum (Eds). School reform critics: The struggle for democratic schooling (pp. 147-158). New York: Peter Lang, (2014a).

8. Sleeter, C. E., Inheriting footholds and cushions: Family legacies and institutional racism. In J. Flores Carmona \& K. V. Luschen (Eds). Crafting critical stories: Toward pedagogies and methodologies of collaboration, inclusion, and voice (pp. 11-26). New York: Peter Lang, (2014b).

9. Soriano-Ayala, E. (Coord.), La práctica educativa intercultural. Madrid: La Muralla, (2004).

10. Soriano-Ayala, E. (Coord.), La mujer en la perspectiva intercultural. Madrid: La Muralla, (2006).

11. Soriano-Ayala, E. (Coord.), Intercultural dad e Neocomunicaicón. Madrid: La Muralla, (2013).

12. Soriano-Ayala, E; González-Jiménez, A.J y Sleeter, C., The participation of inmigrant association in multicultural school in Southern Spain: Some seggestion for cooperation, Revista Publicaciones, 43, 13-28, (2014).

13. Soriano-Ayala, E; González-Jiménez. A.J y Caballero Cala, V. (Eds)., Retos actuales de educación y salud transcultural. Almería: Editorial chthonous and immigrant students and Immigrant students' families, (2014). 